Article

\title{
Aerosol-Cloud Interaction at the Summit of Mt. Fuji, Japan: Factors Influencing Cloud Droplet Number Concentrations
}

\author{
Yoko Iwamoto ${ }^{1,2, *(\mathbb{D})}$, Ayami Watanabe ${ }^{3}$, Ryota Kataoka ${ }^{3}$, Mitsuo Uematsu ${ }^{4,5}$ and Kazuhiko Miura ${ }^{2,6} \mathbb{D}$ \\ 1 Graduate School of Integrated Sciences for Life, Hiroshima University, Higashi-Hiroshima 739-8521, Japan \\ 2 Faculty of Science Division I, Tokyo University of Science, Tokyo 162-8601, Japan; miura@rs.tus.ac.jp \\ 3 Graduate School of Science, Tokyo University of Science, Tokyo 162-8601, Japan; \\ 1209098@alumini.tus.ac.jp (A.W.); $1211041 @$ alumini.tus.ac.jp (R.K.) \\ 4 Atmosphere and Ocean Research Institute, The University of Tokyo, Kashiwa 277-8564, Japan; \\ uematsu@aori.u-tokyo.ac.jp \\ 5 Center for Environmental Science in Saitama, Kazo 347-0115, Japan \\ 6 Laboratory for Environmental Research at Mount Fuji, Tokyo 169-0072, Japan \\ * Correspondence: y-iwamoto@hiroshima-u.ac.jp; Tel.: +81-82-424-4568
}

check for

updates

Citation: Iwamoto, Y.; Watanabe, A.; Kataoka, R.; Uematsu, M.; Miura, K. Aerosol-Cloud Interaction at the Summit of Mt. Fuji, Japan: Factors Influencing Cloud Droplet Number Concentrations. Appl. Sci. 2021, 11, 8439. https://doi.org/10.3390/ app11188439

Academic Editors: Satoshi Irei and Tak W. Chan

Received: 26 July 2021

Accepted: 9 September 2021

Published: 11 September 2021

Publisher's Note: MDPI stays neutral with regard to jurisdictional claims in published maps and institutional affiliations.

Copyright: (c) 2021 by the authors. Licensee MDPI, Basel, Switzerland. This article is an open access article distributed under the terms and conditions of the Creative Commons Attribution (CC BY) license (https:// creativecommons.org/licenses/by/ $4.0 /)$.

\begin{abstract}
To investigate interactions between aerosols and clouds, the size and number concentrations of the cloud condensation nuclei (CCN) and the cloud droplets (CDs) were measured at the summit of Mt. Fuji (altitude $3776 \mathrm{~m})$, Japan. The $\mathrm{CCN}$ number concentrations $\left(N_{\mathrm{CCN}}\right)$ are significantly higher in continental air masses than in air masses from the Pacific Ocean. The hygroscopicity parameter $\kappa$ did not change much for different air mass origins, indicating that aerosol particles in the free troposphere are well mixed. Based on the CD number concentrations $\left(N_{\mathrm{CD}}\right)$, the degree of supersaturation in the ambient air during the cloud-shrouded period was estimated to be $0.15 \%$ (25th percentile) to $0.44 \%$ (75th percentile). To evaluate factors influencing the $N_{\mathrm{CD}}$, measured $N_{\mathrm{CD}}$ were compared to ones calculated based on the Köhler theory using aerosol number size distributions, $\kappa$, and the degree of supersaturation. The results showed that $N_{\mathrm{CD}}$ could not be reproduced satisfyingly when the mean number size distribution or the mean effective supersaturation were used for the calculation. This study highlights the importance of obtaining information about the degree of supersaturation to predict $N_{\mathrm{CD}}$ in the atmosphere.
\end{abstract}

Keywords: cloud condensation nuclei; high alpine site; size distribution; hygroscopicity parameter; water vapor supersaturation

\section{Introduction}

Aerosol particles in the atmosphere can act as cloud condensation nuclei (CCN), which affect the Earth's radiation budget, and consequently the Earth's climate. The number concentration of CCN is a key factor for determining cloud optical properties and precipitation. The CCN activation of an aerosol particle is explained by the Köhler theory [1], and aerosol particles are more likely to act as CCN if the degree of water vapor supersaturation (SS) in the ambient air is higher, the particle size larger, and the particle more hygroscopic. The hygroscopicity of a particle strongly depends on its chemical composition. The relative importance of the size and chemical composition of aerosol particles in determining CCN concentrations at a given $S S$ has been discussed elsewhere (e.g., [2,3]). Several publications state that the CCN activation of aerosol particles is mainly controlled by their size distribution rather than their chemical composition [2]. On the other hand, it has been reported that the chemical composition also matters, especially in regions with a mix of both fresh and aged aerosols [3]. In order to better understand the factors governing CCN number concentrations, it is important to accumulate CCN observation data at various sites. These data can contribute to the refinement of numerical predictions of both $\mathrm{CCN}$ and cloud droplet number concentrations. 
With regard to the $\mathrm{CCN}$ activation of aerosol particles, both the particle size distribution and chemical composition of atmospheric aerosols have been measured at various locations (e.g., [4]), whereas the knowledge about SS is limited. Water vapor SS is an important parameter for $\mathrm{CCN}$ activation of aerosols and is necessary for numerical models predicting cloud/fog formation [5-7]. A critical degree of supersaturation $\left(S S_{c}\right)$ can be determined for a single particle based on the Köhler theory. In the atmosphere, where the size and chemical compositions of aerosol particles are complex, a range of critical supersaturations is generated for a number of CCN. The $S S$ at which the CCN concentration equals the cloud droplet number concentration is termed effective supersaturation $\left(S S_{\text {eff }}\right)$ and is considered that the $S S_{\text {eff }}$ exceeds the $S S_{\mathrm{c}}$ for all $\mathrm{CCN}$ active particles in the atmosphere [1]. Although direct measurement of the $S S$ remains unattainable, it is possible to estimate the $S S_{\text {eff }}$ indirectly from observation data. The reported values of the $S S_{\text {eff }}$ have been limited to Europe [8-11], and $S S_{\text {eff }}$ values from Asian regions have been limited [12].

Observations using airplanes (e.g., [13]), balloons (e.g., [14]) or helicopters (e.g., [10]) are powerful approaches to observe both aerosol and cloud particles in the atmosphere directly. Although these observations by aircraft have provided important findings of aerosol-cloud interactions, it is difficult to get long-term observation data. At mountain sites, orographic clouds frequently form when air flows upward along a mountain slope and the air temperature drops below the dew point due to adiabatic expansion. Observations at mountain sites, therefore, make it possible to observe the $\mathrm{CCN}$ activate into cloud droplets on-site over a long time period. Several studies have reported CCN properties at mountain sites. For example, at Jungfraujoch (altitude $3580 \mathrm{~m}$ ), Switzerland, the impact of the aerosol size distribution on cloud droplet properties [15], CCN activation over the period of one year [16], temporal variations of aerosol hygroscopicity in the free troposphere [17] and scavenge of black carbon in liquid-phase clouds [18] have been studied. Henning et al. [19] reported changes in the hygroscopicity of aerosols through cloud-processing observed at the upwind and downwind sites of Mt. Schmücke (altitude $937 \mathrm{~m}$ ), Germany. Friedman et al. [20] reported the impact of anthropogenic aerosols on CCN activation at Storm Peak Laboratory in Colorado (altitude 3210m), United States. Asmi et al. [9] compared CCN and actually activated particles inside a cloud by using a two-inlet system at Puy-deDôme, France (altitude $1465 \mathrm{~m}$ ), and Hsiao et al. [21] characterized CCN at two different mountain sites in Asia, Doi Ang Kang (altitude 1536 m), Thailand and Mt. Lulin (altitude $2862 \mathrm{~m})$, Taiwan.

In this study, we observed aerosols and clouds at the summit of Mt. Fuji (altitude $3776 \mathrm{~m}$; Figure 1a), Japan, at the highest atmospheric monitoring site downwind of East Asia, during the summer of 2014. Because the summit of Mt. Fuji is mostly in the free troposphere, the observation site is less affected by local air pollutants and thus is a suitable site to observe differences in $\mathrm{CCN}$ characteristics of different air mass origins. During the observation period, the number concentrations of aerosol particles, CCN, and cloud droplets were measured simultaneously. Using the observation data of cloudshrouded periods, the $S S_{\text {eff }}$ of the ambient atmosphere is evaluated. In addition, the factors determining the cloud droplet number concentrations at the summit of Mt. Fuji are discussed, including the $S S_{\text {eff }}$, aerosol size distribution, and the chemical composition of aerosol particles. 
(a)

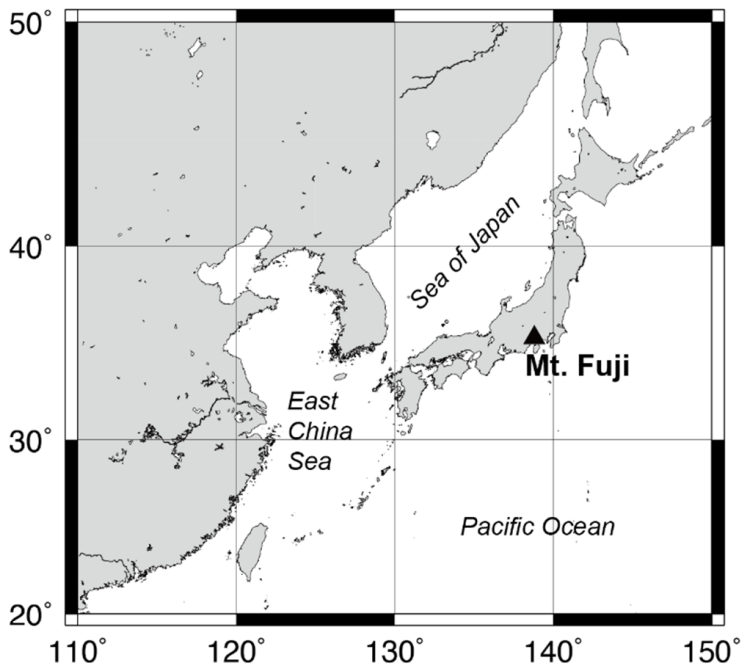

(b)

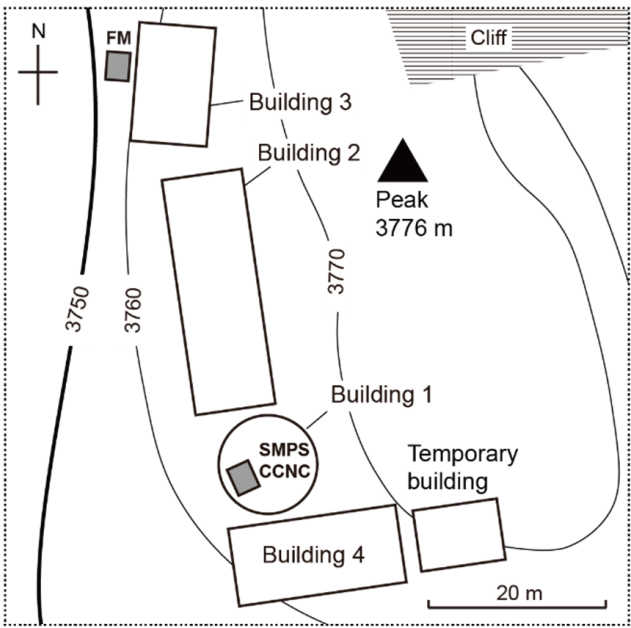

(c)

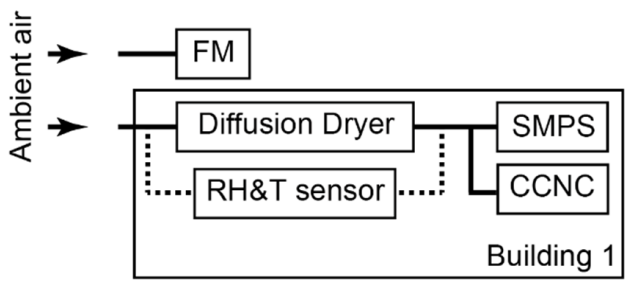

Figure 1. (a) Location of Mt. Fuji (altitude $3776 \mathrm{~m}$ ) in Japan, (b) Schematic of the MFRS with locations of the instruments and (c) schematic diagram of the instrumentation system in building 1 .

\section{Materials and Methods}

\subsection{Observation}

Atmospheric observations were conducted at the Mt. Fuji Research Station (MFRS) $\left(35.36^{\circ} \mathrm{N}, 138.73^{\circ} \mathrm{E}\right.$, altitude $3776 \mathrm{~m}$ ) at the summit of Mt. Fuji (Figure 1a) from 18 July to 20 August of 2014. More details on the MFRS can be found elsewhere (e.g., [22,23]). Briefly, the MFRS consists of five buildings: Building 1, building 2, building 3, building 4 and a temporary building (Figure 1b). Aerosol observations were conducted at buildings 1 and 3 during summer only, when the commercial power supply was available. The instrumental setup used in this study is shown in Figure 1c.

Ambient air was drawn from an air inlet installed on the 2nd floor of building 1 using a conductive silicon tube (I.D. $3 / 8$ in.) and introduced into a diffusion dryer filled with silica gel to dehumidify the sample air down to a relative humidity (RH) of $30 \%$ or less. Temperature and $\mathrm{RH}$ of the sampled air both upstream and downstream of the diffusion dryer were measured by a temperature and humidity sensor (HygroPalm23, Rotronic AG). After the diffusion drying, the size distribution of aerosol particles ranging in size from 10 to $500 \mathrm{~nm}$ in diameter was determined by a scanning mobility particle sizer (SMPS; SMPS3034, TSI Inc., Shoreview, MN, USA). Number concentration of total aerosol particles (condensation nuclei, $\mathrm{CN})\left(N_{\mathrm{CN}}\right)$ was calculated by the sum of the aerosol concentrations of particles in the range of 10 to $500 \mathrm{~nm}$ obtained by the SMPS. The particle loss at the diffusion dryer was calculated to be about $7 \%$ for the minimum size bin of the SMPS (the diameter midpoint is $10.4 \mathrm{~nm}$ ), and less than $3 \%$ above $20 \mathrm{~nm}$ in diameter. The number size distributions were corrected on the basis of this calculation. Note that SPMS data are missing from 18:00 LT (LT $=$ UTC +9 h) 30 July to 07:00 LT 31 July, from 23:00 LT 1 August to 12:00 LT 3 August, and from 07:00 LT 7 August to 11:00 LT 14 August, due to maintenance and instrumental failure. Simultaneously, number concentrations of CCN $\left(N_{\mathrm{CCN}}\right)$ at 6 different SSs $(0.02,0.06,0.16,0.21,0.36$ and $0.55 \%)$ were measured using a CCN counter (CCNC, CCN-100, DMT Inc., Loveland, CO, USA). The CCN data obtained at the $0.02 \%$ and $0.06 \%$ SS conditions were not used for the following analysis because those SSs are below the operating limit $(0.07 \%$; [24]). The SSs were calibrated on-site by 
using $\left(\mathrm{NH}_{4}\right)_{2} \mathrm{SO}_{4}$ particles. For the calibration, the $\left(\mathrm{NH}_{4}\right)_{2} \mathrm{SO}_{4}$ particles were generated by atomization of an aqueous solution of $\left(\mathrm{NH}_{4}\right)_{2} \mathrm{SO}_{4}$ (Kanto Chemical Co., Inc., Tokyo, Japan, $>99.5 \%$ ) and introduced to a diffusion dryer filled with silica gel to dehumidify the $\left(\mathrm{NH}_{4}\right)_{2} \mathrm{SO}_{4}$ aerosol to $\mathrm{RH}$ of $30 \%$ or less. A differential mobility classifier (Model 3081, TSI Inc., Minnesota, USA) was used to classify the particles in the range of 30 to $200 \mathrm{~nm}$ every $10 \mathrm{~nm}$, and the $N_{\mathrm{CN}}$ and $N_{\mathrm{CCN}}$ of the monodisperse aerosol particles were measured by a condensation particle counter (Model 3025A, TSI Inc., Shoreview, MN, USA) and the CCNC, respectively, to obtain CCN activation spectra. For the calibration, a Köhler model similar to the Reference Köhler model described by Brechtel and Kreidenweis [25] was applied.

Number concentrations $\left(N_{\mathrm{CD}}\right)$ and size distributions (from 2 to $50 \mu \mathrm{m}$ in diameter) of cloud droplets (CD) were measured by a fog monitor (FM, FM-100, DMT Inc., Loveland, CO, USA) which was installed outside of building 3 . The most frequent wind direction at the summit of Mt. Fuji was west [26]. Therefore, the FM was installed with its inlet facing the west slope because orographic clouds are likely to be generated by the wind ascending the westerly slope. Meteorological data, including air temperature, $\mathrm{RH}$, atmospheric pressure, precipitation, wind speed and wind direction, were obtained by a meteorological data acquisition system.

\subsection{Data Processing}

The SMPS measured the number size distribution of the aerosol particles every $3 \mathrm{~min}$. The hourly-averaged values of $N_{\mathrm{CN}}$ and the size distributions were used in the following analyses. The CCN counter measured $N_{\mathrm{CCN}}$ every second. It was operated at 6 different $S S$ conditions and each SS condition continued for $10 \mathrm{~min}$. Thus, it took $1 \mathrm{~h}$ to complete one cycle. Averaged values of $N_{\mathrm{CCN}}$ at each $S S$ condition were calculated for every hour. The $N_{\mathrm{CCN}}$ data obtained at the $0.16,0.21,0.36$ and $0.55 \% S S$ s were used for the following analysis. The FM measured the $N_{\mathrm{CD}}$ every $10 \mathrm{~s}$ and hourly-averaged values of $N_{\mathrm{CD}}$ were used for the following analyses.

When aerosol particles are mixed well internally, the particles with diameters larger than the activation diameter $\left(d_{\mathrm{a}}\right)$ can activate as $\mathrm{CCN}$ at a given $S S$. Then, $N_{\mathrm{CCN}}$ can be written as:

$$
N_{\mathrm{CCN}}=\int_{d_{\mathrm{a}}}^{d_{\max }} n(\log d) \operatorname{dlog} d,
$$

where $d$ and $n(\log d)$ are the dry diameter and the number size distribution of the aerosol obtained by SMPS, respectively. Then $d_{\mathrm{a}}$ can be obtained by integrating the particle size distributions. The maximum particle size measured by SMPS, $500 \mathrm{~nm}$, was used as $d_{\max }$.

The relationship between the saturation ratio, $S$, and the droplet diameter is described by the Köhlor theory [1]. The theory can be re-written by using the hygroscopicity parameter $\kappa$ [27] as follows:

$$
S=\frac{d_{\mathrm{drop}}^{3}-d^{3}}{d_{\mathrm{drop}}^{3}-d^{3}(1-\kappa)} \exp \left(\frac{4 \sigma_{\mathrm{s} / \mathrm{a}} M_{\mathrm{w}}}{R T \rho_{\mathrm{w}} d_{\mathrm{drop}}}\right),
$$

where $d_{\text {drop }}$ is the droplet diameter, $\sigma_{\mathrm{s} / \mathrm{a}}$ is the surface tension at the solution-air interface, $M_{\mathrm{W}}$ is the molecular weight of water, $R$ is the universal gas constant, $T$ is the droplet temperature, and $\rho_{\mathrm{w}}$ is the density of pure water. Note that the relationship between supersaturation, $S S$, and saturation ratio, $S$, is as below:

$$
S S=(S-1) \times 100 \% .
$$

Equation (2) can be simplified as follows [27,28]:

$$
S=\exp \left(\sqrt{\frac{4 A^{3}}{27 \kappa d^{3}}}\right)
$$


The parameter $A$ represents Kelvin's term and can be written as:

$$
A=\frac{4 \sigma_{\mathrm{s} / \mathrm{a}} M_{\mathrm{w}}}{R T \rho_{\mathrm{w}}}
$$

In Equation (5), $A \approx 0.66 / T$ (in $\mathrm{mm}$ ) can be used [29]. The $\kappa$ of ambient aerosol was then calculated for each $S S$ condition $(0.16,0.21,0.36$ and $0.55 \%)$ of the CCN counter by using $d$ as $d_{\mathrm{a}}$ in Equation (4):

$$
\kappa=\frac{4 A^{3}}{27 d_{a}^{3} \ln ^{2} S} .
$$

By applying Equation (1) and replacing $N_{\mathrm{CCN}}$ by $N_{\mathrm{CD}}$, the activation diameters $\left(d_{\mathrm{a}}, \mathrm{CD}\right)$ under ambient $S S$ conditions were calculated based on the aerosol size distributions:

$$
N_{\mathrm{CD}}=\int_{d_{\mathrm{a}, \mathrm{CD}}}^{d_{\max }} n\left(\log d_{\mathrm{p}}\right) \operatorname{d} \log d_{\mathrm{p}}
$$

To estimate the $S S_{\text {eff }}$ of the clouds observed at the MFRS, we used the regression curve of the relationship between mean $d_{\mathrm{a}}$, calculated by Equation (1), and $S S$ obtained by the CCN measurements. Using the data collected by the FM, the liquid water content (LWC) and the effective radius $\left(R_{\text {eff }}\right)$ of the cloud droplets were calculated using the following equations [15], respectively:

$$
\begin{gathered}
L W C=\frac{\pi}{6} \rho_{\mathrm{w}} \sum_{\mathrm{i}} n_{\mathrm{i}} d_{\mathrm{i}}^{3}, \\
R_{\text {eff }}=\frac{1}{2} \sum_{\mathrm{i}} n_{\mathrm{i}} d_{\mathrm{i}}^{3} / \sum_{\mathrm{i}} n_{\mathrm{i}} d_{\mathrm{i}}^{2},
\end{gathered}
$$

where, $n_{\mathrm{i}}$ is the number concentration of cloud droplets and $d_{\mathrm{i}}$ is the geometric mean diameter of each size bin set by the FM.

\subsection{Classification of Air Mass Transport Pathways}

Backward air mass trajectories for the past $72 \mathrm{~h}$ were calculated every hour using the hybrid single-particle Lagrangian integrated trajectory (HYSPLIT) model [30,31]. The trajectories were classified based on their vertical and horizontal transport pathways. Vertical pathways that transported constantly above $2000 \mathrm{~m}$ altitude were classified as free troposphere (FT). For all others, the trajectories were classified as originating from the planetary boundary layer. For the horizontal pathways, the trajectories were classified into four categories: Continental, Pacific, and Others, according to where each trajectory started (Figure 2). The trajectories that started from the Asian continent and Pacific Ocean were classified as Continental and Pacific, respectively. The trajectories classified as Others included those originating from the marginal seas (East China Sea, Sea of Japan and Okhotsk Sea) or those positioned over the Japanese mainland for more than $48 \mathrm{~h}$.
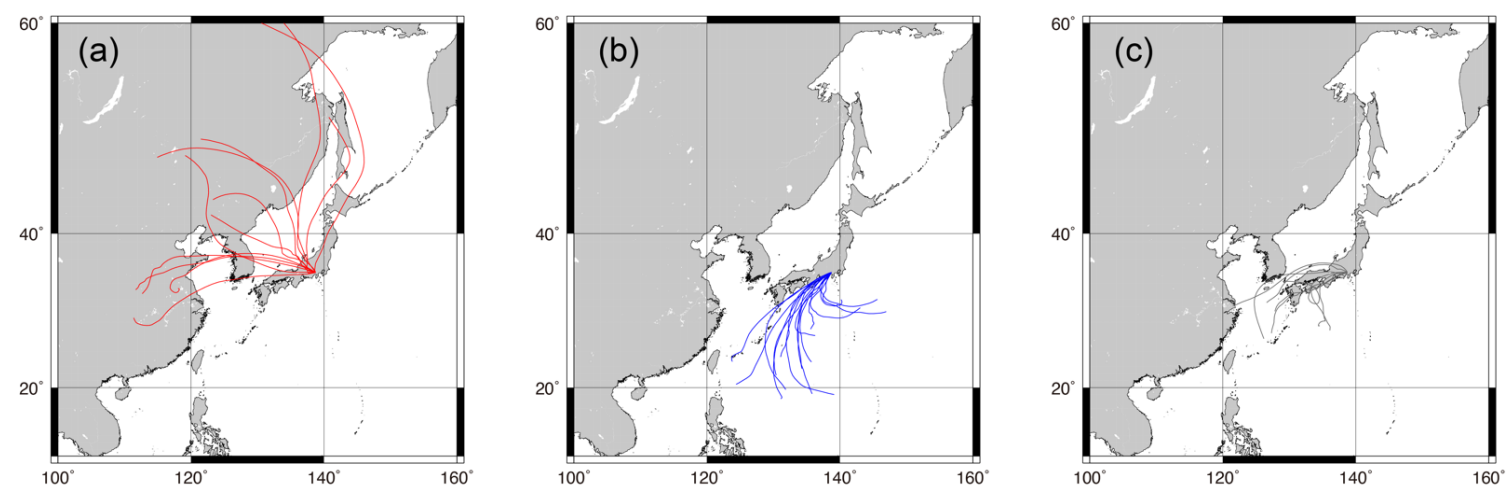

Figure 2. Examples of trajectories classified (a) Continental, (b) Pacific and (c) Others. For the vertical pathways, only trajectories classified as free troposphere (FT) are illustrated. 


\section{Results and Discussion}

\subsection{Overview}

Figure 3 shows temporal variations in (a) air mass origins, (b) air pressure, precipitation, (c) air temperature, ambient $\mathrm{RH}$ (d) wind speed and wind direction throughout the observation period. About $84 \%$ of the backward trajectories were classified as FT (Figure 3a), indicating that the MFRS was in the free troposphere for most of the observation period. Thus, it is possible to see the effect of long-range transport of aerosols of different air mass origins on CCN characteristics. The trajectories classified as Continental are frequently observed in the early part of the observation period (20 to $29 \mathrm{July}$ ), whereas, those classified as Pacific are observed from about halfway through the observation period onwards ( 2 to 20 August) (Figure 3a). The mean air pressure during the observation period was $648.7 \mathrm{hPa}$. The drops of air pressure were observed on $27 \mathrm{July}$ and 9 to 10 August, respectively, due to the passing of a cold front and the effect of the typhoon Halong (Figure 3b). The mean air temperature was $5.9^{\circ} \mathrm{C}$, with a range from 0.4 to $14.4{ }^{\circ} \mathrm{C}$ (Figure 3c). At the summit, northerly winds were dominant in July. In August, westerly winds prevailed except around 8 to 11 August, when easterly winds were observed along with the typhoon Halong passing through Japan islands (Figure 3d).

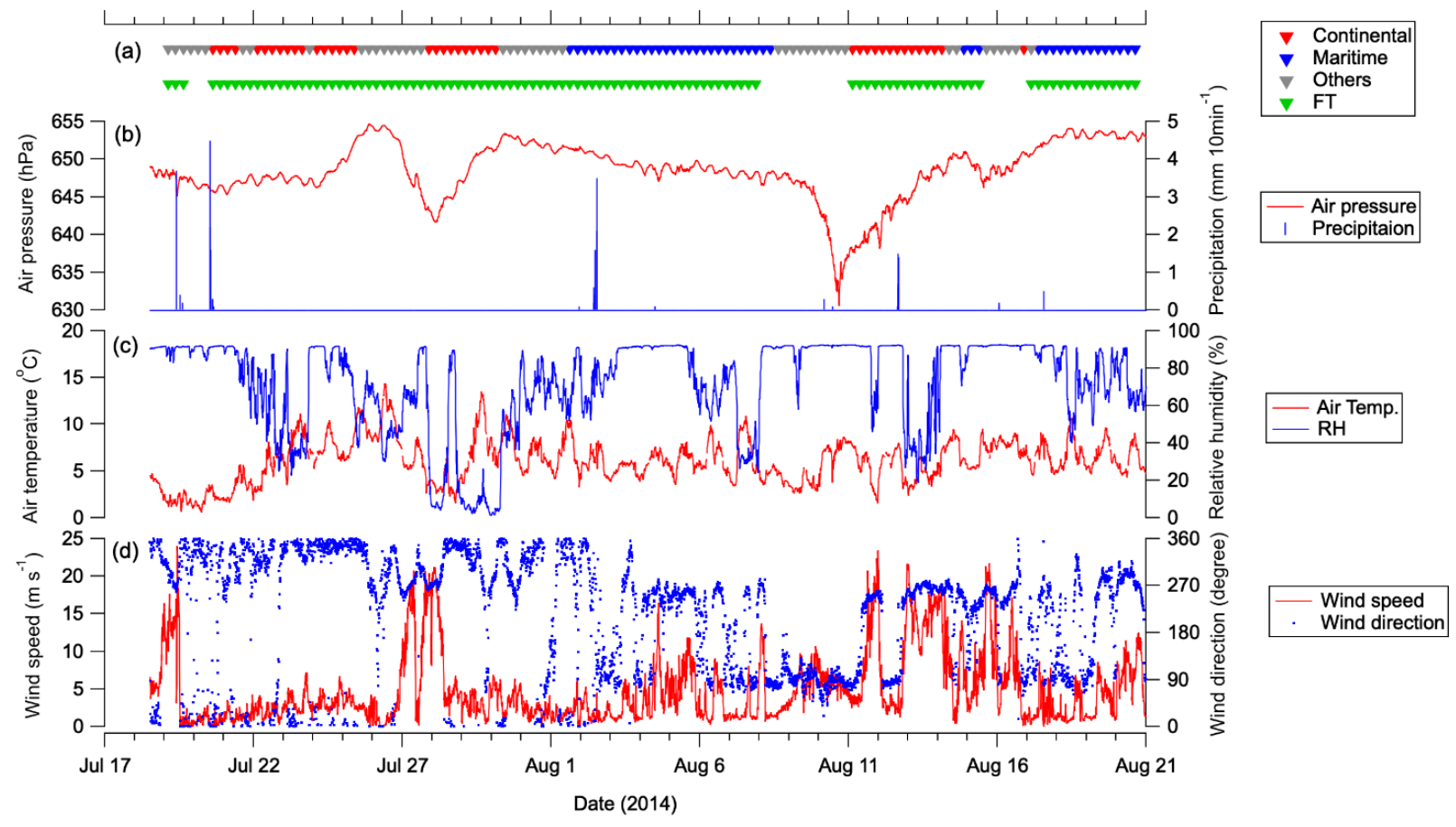

Figure 3. Temporal variations of (a) air mass origins, (b) air pressure (red line), precipitation (blue sticks), (c) air temperature (red line), relative humidity (blue line), (d) wind speed (red lines) and wind direction (blue dots).

Figure 4 shows temporal variations in (a) air mass origins, (b) number size distributions of aerosol particles with 10 to $500 \mathrm{~nm}$ in diameter, (c) $N_{\mathrm{CN}}$ and $N_{\mathrm{CCN}}$ at each $S S$ condition, and (d) LWC. Cloud-shrouded periods were defined as periods when the LWC is greater than $0.01 \mathrm{~g} \mathrm{~m}^{-3}$. As a result, $40 \%$ of the observation period was classified as cloud-shrouded (Figure 4d). In the following analysis, the data collected when (1) the backward trajectories were classified as FT, and (2) when the SMPS was in operation, were used. 


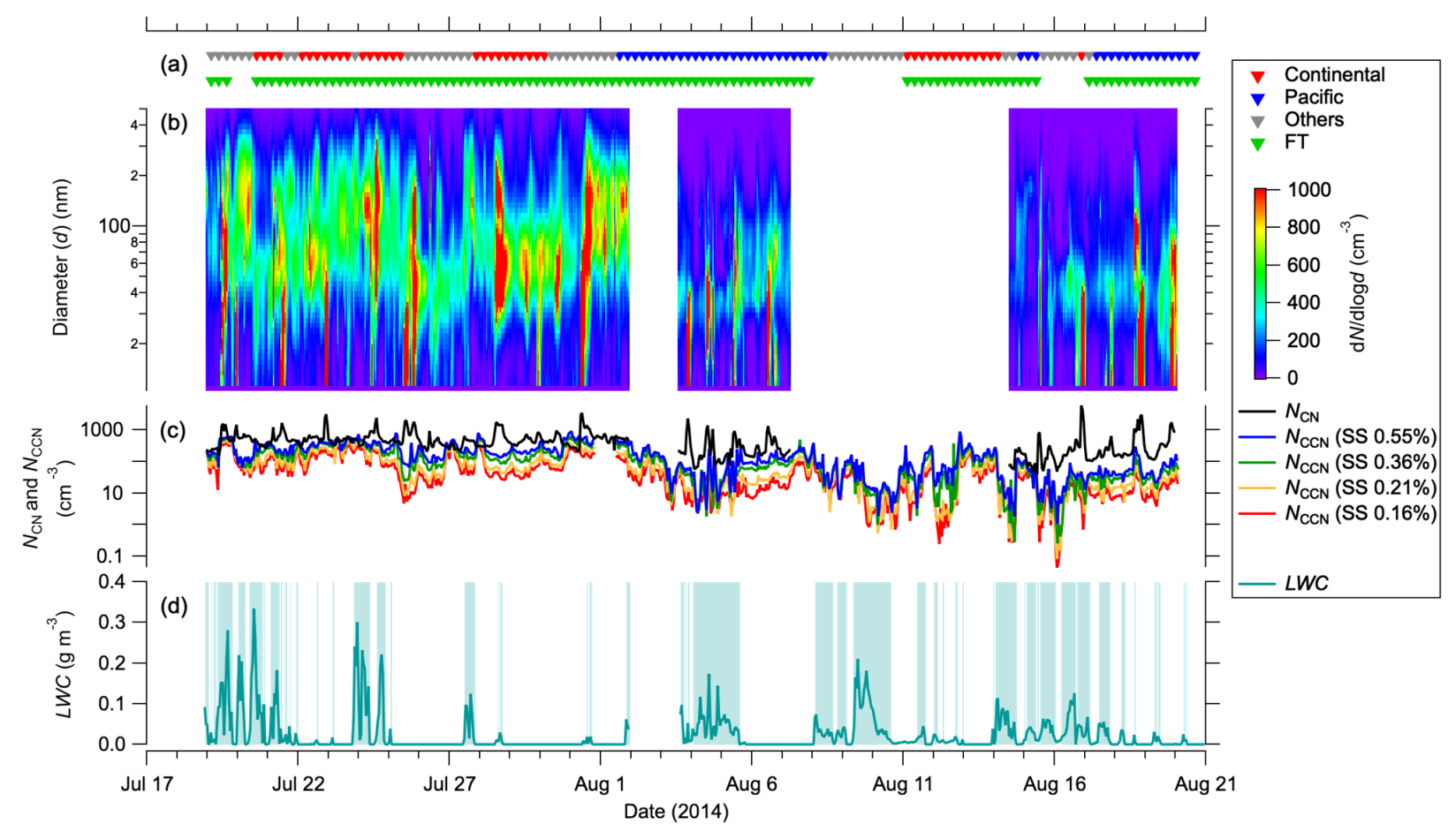

Figure 4. Temporal variation of (a) air mass origins, (b) number size distributions (10-500 nm), (c) total particle concentrations $\left(N_{\mathrm{CN}}\right)$ and $\mathrm{CCN}$ concentrations $\left(N_{\mathrm{CCN}}\right)$ at each $S S$ condition, and (d) Liquid water content $(L W C)$. The green shading in (d) indicates cloud-shrouded periods.

\subsection{CCN Properties and Their Relationship to Air Mass Origins}

The mean value of $N_{\mathrm{CN}}$ for the entire observation period was $527.7 \mathrm{~cm}^{-3}$. By air mass origin, the mean values of $N_{\mathrm{CN}}$ of the Continental, Pacific and Others periods were 617.9, 391.5 and $524.5 \mathrm{~cm}^{-3}$, respectively. The 25th percentile, median, mean and 75th percentile values of $N_{\mathrm{CN}}$ and $N_{\mathrm{CCN}}$ are summarized in Tables 1 and 2, respectively. The mean values of $N_{\mathrm{CN}}, N_{\mathrm{CCN}}$ and the activation ratio $\left(N_{\mathrm{CCN}} / N_{\mathrm{CN}}\right)$ at each $S S$ condition showed clear differences between the periods classified as Continental and Pacific; those values were significantly higher for the Continental air masses than for the air masses from the Pacific (Figure 5a,b). The same trend was observed in a previous study at the MFRS [32]. The mean values of $\kappa$ were calculated by Equation (6), to be 0.25 to 0.28 at each $S S$ condition over the analysis period. These values were similar to values observed at other mountain sites, Jungfraujoch ( 0.13 to 0.29 at $S S s$ s.12\% to $1.18 \%$; [16]) and Storm Peak Laboratory $(0.2 \pm 0.15$ at SSs $0.07 \%$ to $0.72 \%$; [20]). The recent study summarized aerosol chemistry at alpine sites and aircraft measurements and reported that the main components of submicron non-refractory aerosol in high-altitude sites are sulfate, ammonium and organics [33]. Additionally, it was reported that ammonium and sulfate are the main inorganic ion species in the aerosol collected at the summit of Fuji [34]. The $\kappa$ values observed at MFRS during summer can be explained by the mixtures of inorganics ( $\kappa=0.61$ to 1.28 ; [27]) and organics $(\kappa=0$ to 0.2 ; [35]). Black carbon $(\kappa \cong 0)$ may affect the aerosol composition at MFRS especially when the airmass comes from the planetary boundary layer [36] although it could not be a major component. For the different air mass origins, the mean values of $k$ are 0.26 to 0.30 (Continental), 0.19 to 0.28 (Pacific) and 0.24 to 0.30 (Others) (Figure $5 \mathrm{~d}$ ). In the free troposphere, aerosol particles have a longer lifetime because they are less susceptible to deposition. Therefore, particles in the free troposphere are more aged and well-mixed than those in the planetary boundary layer (e.g., [33]). This could cause the relatively uniform chemical composition made up of mainly sulfate and aged (oxidized) organics regardless of airmass origins. Because smaller particles require larger $S S$ to activate, each $\kappa$ value at a certain $S S$ reflects the chemical composition of the particles around $d_{\mathrm{a}}$. The $\kappa$ 
values are relatively uniform regardless of the particle size (Figure $5 c, d$ ), indicating that no size dependency of the chemical composition of the aerosol at the MFRS during summer exists. This result differs from other CCN studies at non-alpine sites (e.g., [37-39]), in which smaller particles were shown to be less hygroscopic, suggesting that the aerosol in the free troposphere is well-mixed compared to the aerosol sampled closer to the sources.

Table 1. The 25th percentile, median, mean and 75th percentile values of $N_{\mathrm{CN}}$. Number of data $(N)$ for each air mass category is also indicated.

\begin{tabular}{cccccc}
\hline & \multicolumn{5}{c}{$N_{\mathrm{CN}}\left(\mathbf{c m}^{-3}\right)$} \\
\cline { 2 - 5 } & $\boldsymbol{N}$ & 25th & Median & Mean & 75th \\
\hline Entire period & 502 & 231.0 & 414.2 & 527.7 & 590.7 \\
Continental & 167 & 383.3 & 459.4 & 617.9 & 595.1 \\
Pacific & 188 & 153.8 & 205.1 & 391.5 & 433.4 \\
Others & 147 & 272.9 & 450.6 & 524.5 & 610.7 \\
\hline
\end{tabular}

Table 2. The 25th percentile, median, mean and 75th percentile values of $N_{C C N}$ at each $S S$. Number of data $(N)$ for each air mass category is also indicated.

\begin{tabular}{|c|c|c|c|c|c|c|c|c|c|c|}
\hline & \multicolumn{6}{|c|}{$N_{\mathrm{CCN}}\left(\mathrm{cm}^{-3}\right)(0.16 \% \mathrm{SS})$} & \multicolumn{4}{|c|}{$N_{\mathrm{CCN}}\left(\mathrm{cm}^{-3}\right)(0.21 \% \mathrm{SS})$} \\
\hline & $N$ & 25th & Median & Mean & 75th & $N$ & 25th & Median & Mean & 75 th \\
\hline Entire period & 487 & 14.2 & 41.3 & 80.9 & 117.8 & 491 & 24.4 & 61.3 & 107.8 & 160.8 \\
\hline Continental & 167 & 44.5 & 82.6 & 176.1 & 117.2 & 167 & 68.1 & 114.9 & 155.3 & 228.0 \\
\hline Pacific & 179 & 7.6 & 12.8 & 22.4 & 24.8 & 184 & 14.1 & 22.9 & 34.0 & 39.4 \\
\hline \multirow[t]{3}{*}{ Others } & 141 & 30.1 & 62.3 & 112.3 & 181.2 & 140 & 43.1 & 90.4 & 147.9 & 230.2 \\
\hline & \multicolumn{6}{|c|}{$N_{\mathrm{CCN}}\left(\mathrm{cm}^{-3}\right)(0.36 \% \mathrm{SS})$} & \multicolumn{4}{|c|}{$N_{\mathrm{CCN}}\left(\mathrm{cm}^{-3}\right)(0.55 \% \mathrm{SS})$} \\
\hline & $N$ & 25th & Median & Mean & 75th & $N$ & 25th & Median & Mean & 75th \\
\hline Entire period & 491 & 50.2 & 113.3 & 169.7 & 260.2 & 492 & 76.2 & 181.5 & 224.2 & 341.1 \\
\hline Continental & 167 & 135.1 & 204.2 & 239.9 & 324.4 & 167 & 206.2 & 269.7 & 310.0 & 395.2 \\
\hline Pacific & 185 & 27.9 & 46.2 & 64.4 & 73.3 & 185 & 37.8 & 64.6 & 92.5 & 103.0 \\
\hline Others & 139 & 91.4 & 158.2 & 225.4 & 355.6 & 140 & 138.2 & 229.9 & 295.7 & 460.5 \\
\hline
\end{tabular}

The $\kappa$ values are similar between air mass origins, while the particle size distribution is strongly dependent on the particle source (Figure 6). The mode diameter of the aerosol particles of Continental origin $(58 \mathrm{~nm})$ is significantly larger than that of Pacific origin $(24 \mathrm{~nm})$. It is thought that aging processes, such as condensation, coagulation and cloud processing, change number size distributions (e.g., [40]). The aerosols of Continental origin are more likely to be affected by these aging processes because an abundant supply of gaseous and particulate substances from these sources is likely. The larger the size of the aerosol, the easier it is to become activated CCN. From the above results, it can be concluded that the particle size distribution is the most important factor determining $N_{\mathrm{CCN}}$ in the free tropospheric airmass at the MFRS during summer.

\subsection{Evaluation of $S S_{\text {eff }}$ and Cloud Droplet Properties}

The cloud droplet concentration $\left(N_{\mathrm{CD}}\right)$ during the cloud-shrouded periods ranged from 1.6 to $389.1 \mathrm{~cm}^{-3}$ (mean: $78.3 \mathrm{~cm}^{-3}$ ). By using Equation (7), the activation diameters $\left(d_{\mathrm{a}, \mathrm{CD}}\right)$ under ambient $S S$ conditions were calculated and they ranged from 31.6 to $379.6 \mathrm{~nm}$. To estimate the $S S_{\text {eff }}$ of the clouds observed at the MFRS, we used the regression curve of the relationship between mean $d_{\mathrm{a}}$ and SS obtained by the CCN measurements (Figure $5 \mathrm{c}$ ):

$$
d_{\mathrm{a}, \mathrm{CD}}=46.32 \times S S_{\mathrm{p}}{ }^{-0.65} \text {. }
$$



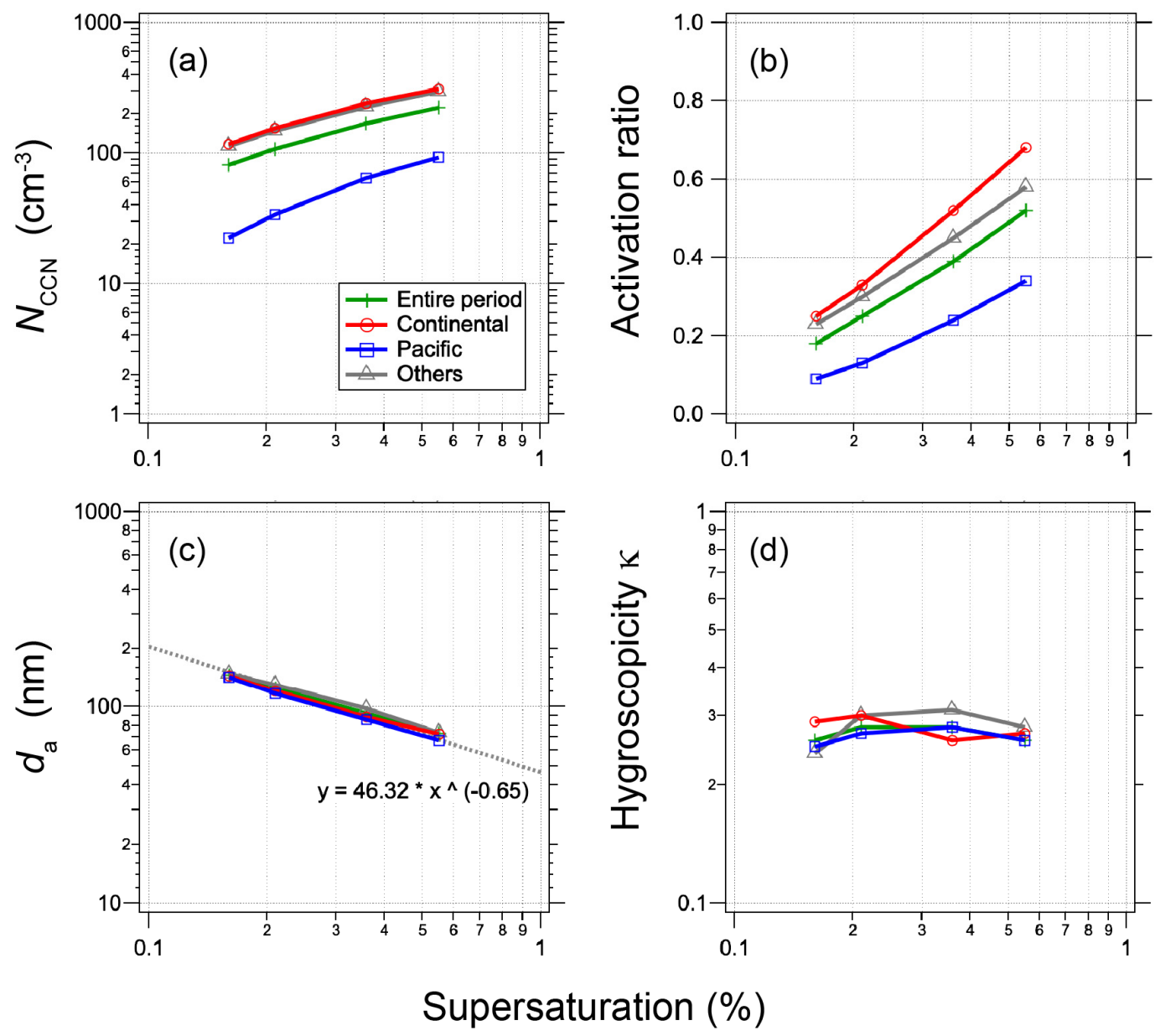

Figure 5. Relationship between water vapor supersaturation (\%) and the median values of (a) number concentration of $\mathrm{CCN}\left(N_{\mathrm{CCN}}\right)(\mathbf{b})$ activation ratio $\left(N_{\mathrm{CCN}} / N_{\mathrm{CN}}\right)(\mathbf{c})$ activation diameter $\left(d_{\mathrm{a}}\right)$ and $(\mathbf{d})$ hygroscopicity parameter $(\kappa)$, classified according to air mass origins. Green, red, blue, and gray lines and markers represent the entire period, Continental, Pacific, and Others airmass periods, respectively.

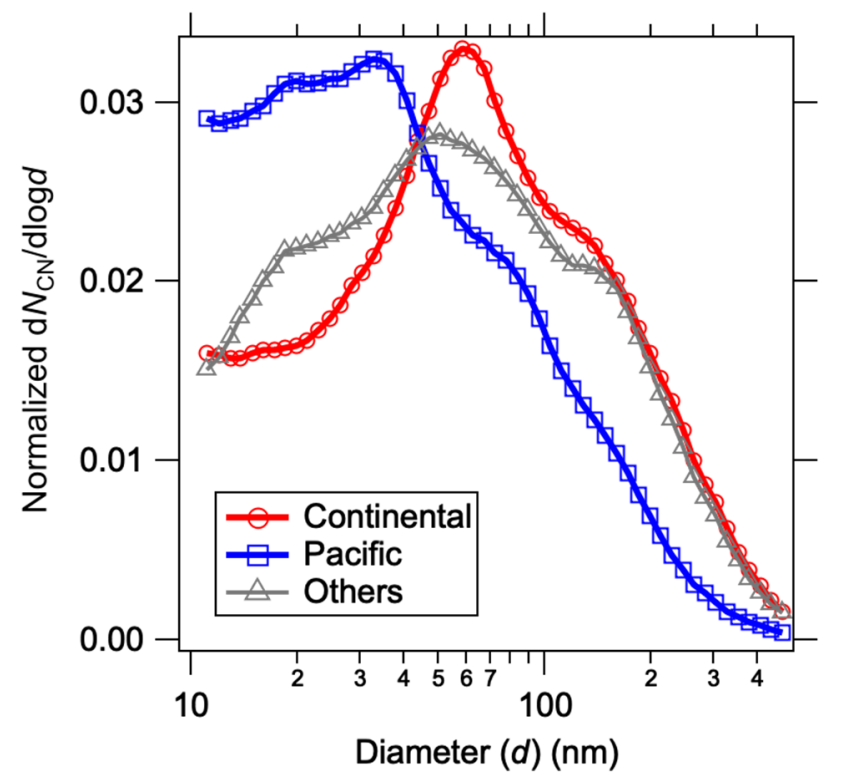

Figure 6. Normalized number size distribution of the aerosol particles at the MFRS classified according to air mass origins. 
Based on these calculations, the $S S_{\text {eff }}$ during the cloud-shrouded periods is estimated to be $0.15 \%$ (25th percentile) to $0.44 \%$ (75th percentile) (Figure 7). Asmi et al. [9] estimated the in-cloud SS at the Puy-de-Dôme station (altitude $1465 \mathrm{~m}$ ) to be $0.1 \%$ to $0.6 \%$, and Hammer et al. [11] reported an $S S_{\text {eff }}$ of cumulus and shallow-layer clouds at Jungfraujoch (attitude $3580 \mathrm{~m}$ ) of $0.37 \%$ to $0.5 \%$ and $0.17 \%$ to $0.3 \%$, respectively. The values of $S S_{\text {eff }}$ calculated in this study were comparable to the values of $S S$ of clouds at mountain sites in previous studies. When compared to air mass origins, no significant differences among the $S S_{\text {eff }}$ of Continental, Pacific and Others were apparent (Figure 7). A positive correlation ( $R=0.54, p<0.01$ ) between $N_{\mathrm{CD}}$ and $N_{\mathrm{CCN}}$ under the $0.21 \% S S$ condition, which is close to the median value of $S S_{\text {eff }}$, is observed. The points are scattered around an 1:1 line and large scatter is observed when $L W C$ is lower (Figure 8).

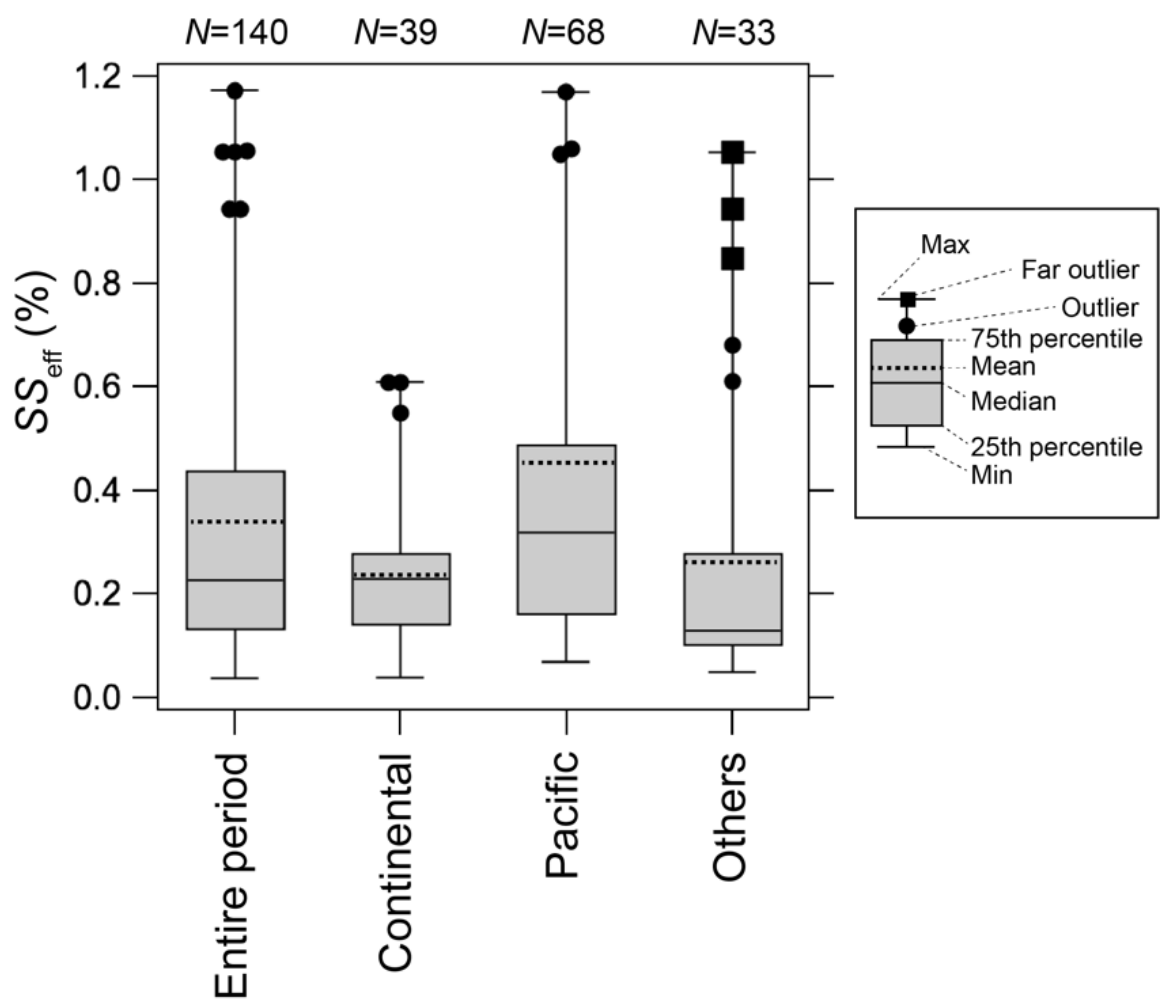

Figure 7. Effective supersaturation $\left(S S_{\text {eff }}\right)$ of clouds at the MFRS classified according to air mass origins. Number of data $(N)$ for each group is indicated at the top of the panel.

Parameters characterizing the clouds at the MFRS are summarized in Table 3. Note that these parameters were obtained only during the cloud-shrouded periods. It was reported that $S S$ tends to be higher at higher updraft wind velocities (e.g., [8]), because adiabatic expansion is an important factor for the determination of $S S$ in a cloud. In this study, the updraft wind velocity was not measured. Hammer et al. [11] proposed a method to calculate the updraft velocity by multiplying the horizontal wind speed by the tangent of the angle of the mountain slope:

$$
w=v_{\mathrm{h}} \times \tan \theta,
$$

where $w, v_{\mathrm{h}}$ and $\theta$ are updraft velocity, horizontal velocity, and the angle of mountain slope, respectively. Equation (11) assumes that the airmass rises along the slope of the mountain, otherwise it is overestimated. Here, it was used as a standard of the maximum value of the updraft velocity. As for the angle of the mountain slope, $38^{\circ}$ (the angle of west side) was used. Note that Mt. Fuji is a stratovolcano with conical shape, and the angle of the slope is almost same regardless of the direction. The mean updraft velocity was slightly higher when the airmass origin was Pacific than when it was Continental. On the whole, 
however, the difference of updraft velocities by the airmass origin was not remarkable. The topography of the summit of Mt. Fuji is complicated due to the existence of a crater. This will disturb the air stream, so the actual updraft velocity was likely to be different from the estimate. In the future, it will be necessary to monitor the updraft velocity on site by installing multiple ultrasonic anemometers to understand the factor controlling SS.

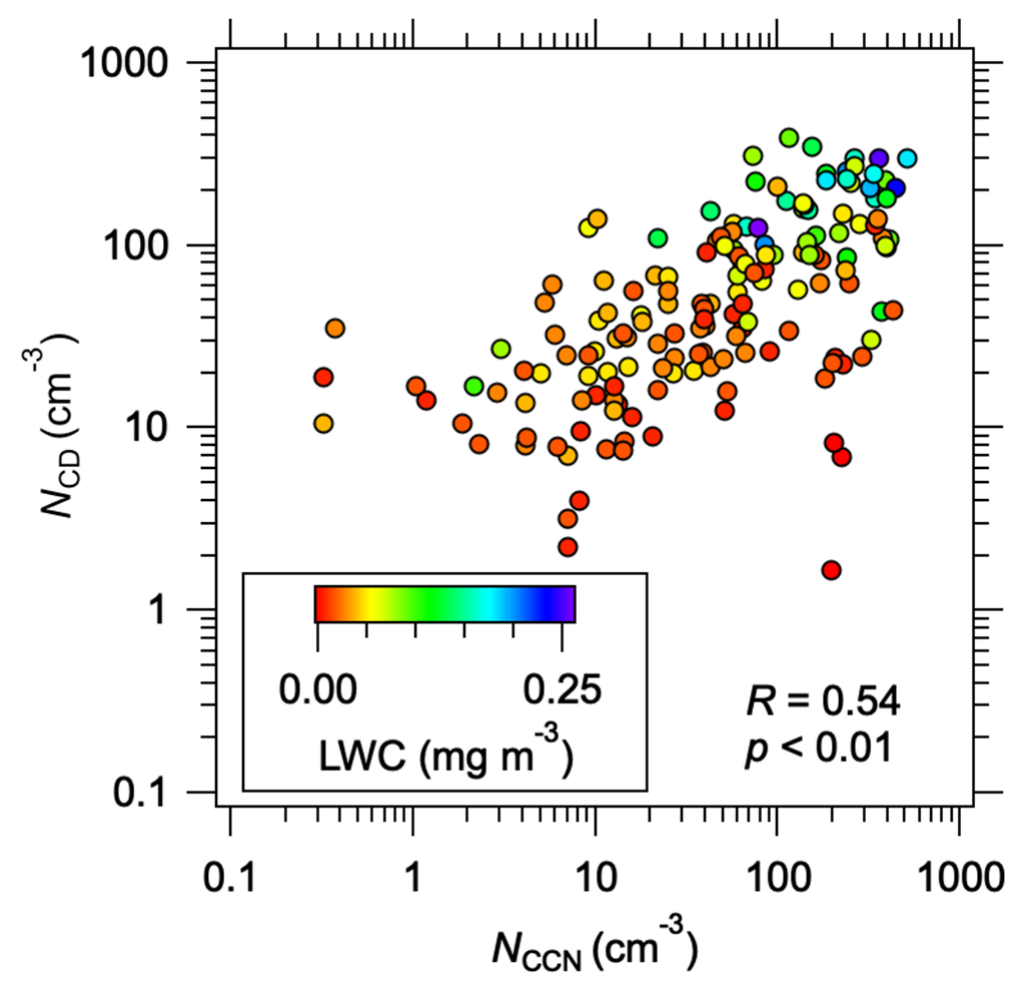

Figure 8. Relationship between $N_{\mathrm{CD}}$ and $N_{\mathrm{CCN}}$ under $0.21 \% \mathrm{SS}$.

Table 3. Mean values of $S S_{\text {eff }}, w, N_{\mathrm{CD}}, L W C$ and $R_{\text {eff }}$ for clouds at the MFRS classified according to air mass origin. Standard deviations are indicated in parentheses.

\begin{tabular}{ccccc}
\hline & & & Air Mass Origin & \\
& Entire Period & Continental & Pacific & Others \\
\hline$S S_{\text {eff }}(\mathbf{\%})$ & $0.34(0.34)$ & $0.24(0.14)$ & $0.44(0.41)$ & $0.26(0.26)$ \\
$w\left(\mathbf{m ~ s}^{-1}\right)$ & $1.29(1.21)$ & $1.03(1.32)$ & $1.40(0.83)$ & $1.37(1.63)$ \\
$\boldsymbol{L W C}\left(\mathbf{g ~ m}^{-3}\right)$ & $0.05(0.05)$ & $0.08(0.06)$ & $0.03(0.02)$ & $0.06(0.05)$ \\
$\boldsymbol{N}_{\mathbf{C D}}\left(\mathbf{c m}^{-3}\right)$ & $78(78)$ & $144(92)$ & $36(32)$ & $86(65)$ \\
$\boldsymbol{R}_{\text {eff }}(\mu \mathrm{m})$ & $8.1(2.5)$ & $6.5(1.7)$ & $9.3(2.5)$ & $7.6(2.1)$ \\
\hline
\end{tabular}

The values of $L W C$ range from 0.01 to $0.26 \mathrm{~g} \mathrm{~m}^{-3}$, and were similar to those of stratocumulus, stratus and fog $\left(0.05-0.3 \mathrm{~g} \mathrm{~m}^{-3}\right.$; [41]) (Table 3) There was a clear difference in $N_{\mathrm{CD}}$ between air masses of Continental and Pacific origin as observed in $N_{\mathrm{CCN}}$ (Figure 5a). The mean $N_{C D}$ in Continental airmass $\left(144 \mathrm{~cm}^{-3}\right)$ was similar to the annual mean value in East Asia region estimated by the satellite observation $\left(136.9 \mathrm{~cm}^{-3}\right)$ [42], however, the mean $N_{\mathrm{CD}}$ during the entire period $\left(78 \mathrm{~cm}^{-3}\right)$ was less than the annual mean value. This could be caused by the seasonality of prevailing winds in East Asia: winds come from the Pacific under the Pacific high-pressure system during summer, but in other seasons, winds come mostly from the Asia continent. It is considered that the period (summer) in which we conducted our observations was the season with the lowest $N_{\mathrm{CD}}$ of the year in the region. The normalized size distributions of $N_{C D}$ were illustrated in Figure 9. The shapes of size distributions resembled each other, but the CDs larger than $20 \mu \mathrm{m}$ were more in the Pacific airmass. The calculated $R_{\text {eff }}$ were 6.5 and $9.3 \mu \mathrm{m}$, respectively, in the Continental 
and Pacific airmasses. If the water content is constant in the atmosphere, $R_{\text {eff }}$ of cloud particles decreases as $N_{\mathrm{CD}}$ increases. This results in a change of the optical properties of the cloud and is known as the Twomey effect [43]. In this study, LWC of Continental airmasses is larger than that of Pacific airmass. This could be due to the higher $N_{C D}$ of Continental air masses, because $L W C$ was a function of both number and size. Although the values of LWC differed, the inversely proportional relationship between $N_{\mathrm{CD}}$ and $R_{\text {eff }}$ was still observed between Continental and Pacific airmasses.

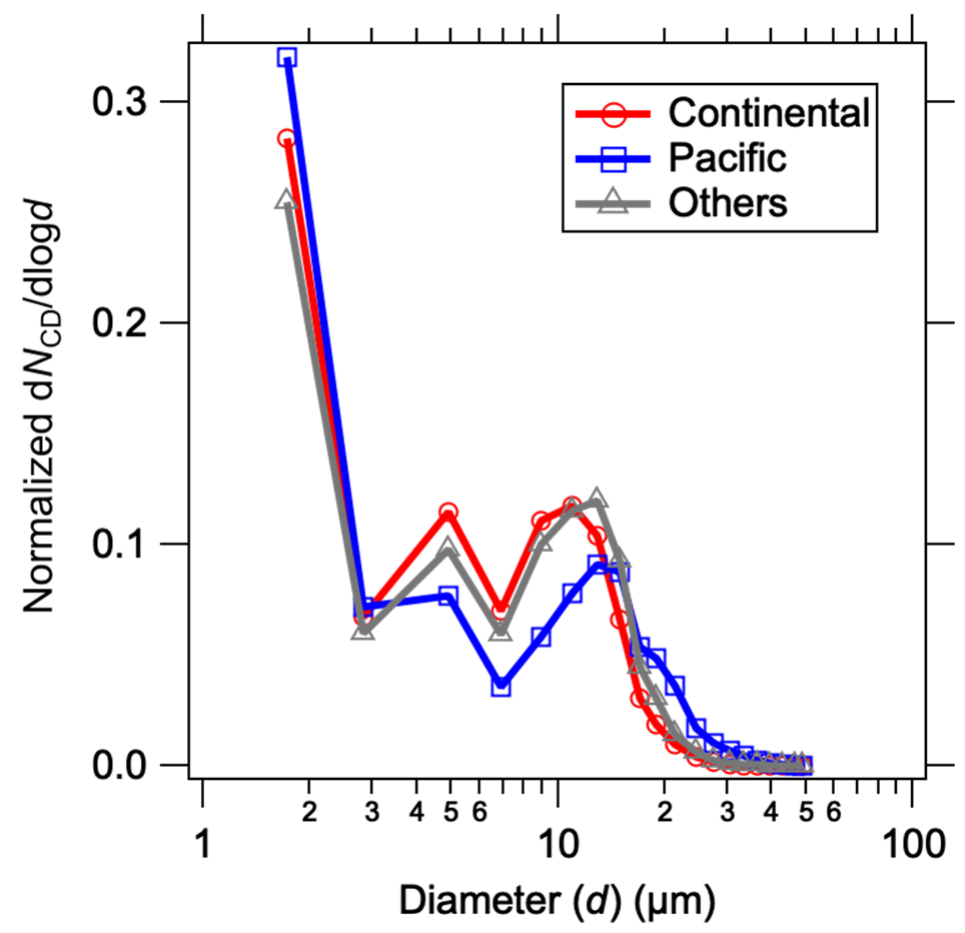

Figure 9. Normalized number size distribution of the cloud droplets at the MFRS classified according to air mass origins.

\subsection{Factors Controlling the Cloud Droplet Concentration}

To investigate factors controlling the $N_{\mathrm{CD}}, N_{\mathrm{CD}}$, cal was calculated by using the aerosol number size distribution, the hygroscopicity parameter $(\kappa)$, and the $S S_{\text {eff. Where }} \kappa$ and the ambient $S S$ were known, the activation diameter $\left(d_{\mathrm{a}, \mathrm{cal}}\right)$ can be calculated based on the Köhler theory (Equations (2) or (4)). Then, the $N_{C D}$ can be calculated by inputting the calculated $d_{\mathrm{a}}$, cal values and the size distribution into Equation (1). Here, each $N_{\mathrm{CD}}$, cal was calculated for the following three patterns: (1) mean size distribution shape, (2) mean $S S_{\text {eff }}$, and (3) mean hygroscopicity parameter $\kappa$ (at $0.21 \%$ SS of the CCN measurements) for the cloud-shrouded periods. Then the calculated value was compared to the measured value $\left(N_{\mathrm{CD}}\right)$. As a result, relative errors were $278.7 \%, 139.4 \%$ and $43.4 \%$, respectively, when size distributions, $S S_{\text {eff }}$ and $\kappa$ were fixed to their mean values. Therefore, the $N_{\mathrm{CD}}$, cal can be estimated with $\pm 50 \%$ error by using the mean value of $\kappa$ during cloud-shrouded periods (Figure 10c). However, the $N_{\mathrm{CD}}$, cal cannot be reproduced well if the mean number size distribution or the mean $S S_{\text {eff }}$ are used in the calculations (Figure 10a,b). These results indicate that the size distribution is the most important factor controlling the cloud droplet number concentration at the MFRS, but that the concentration can be reproduced reasonably well when using a representative aerosol chemical composition. In addition, the evaluation of the $S S_{\text {eff }}$ seems to be of greater importance than the chemistry for accurately predicting cloud droplet number concentrations at the MFRS during summer, where well-mixed, free tropospheric aerosol is observed. 


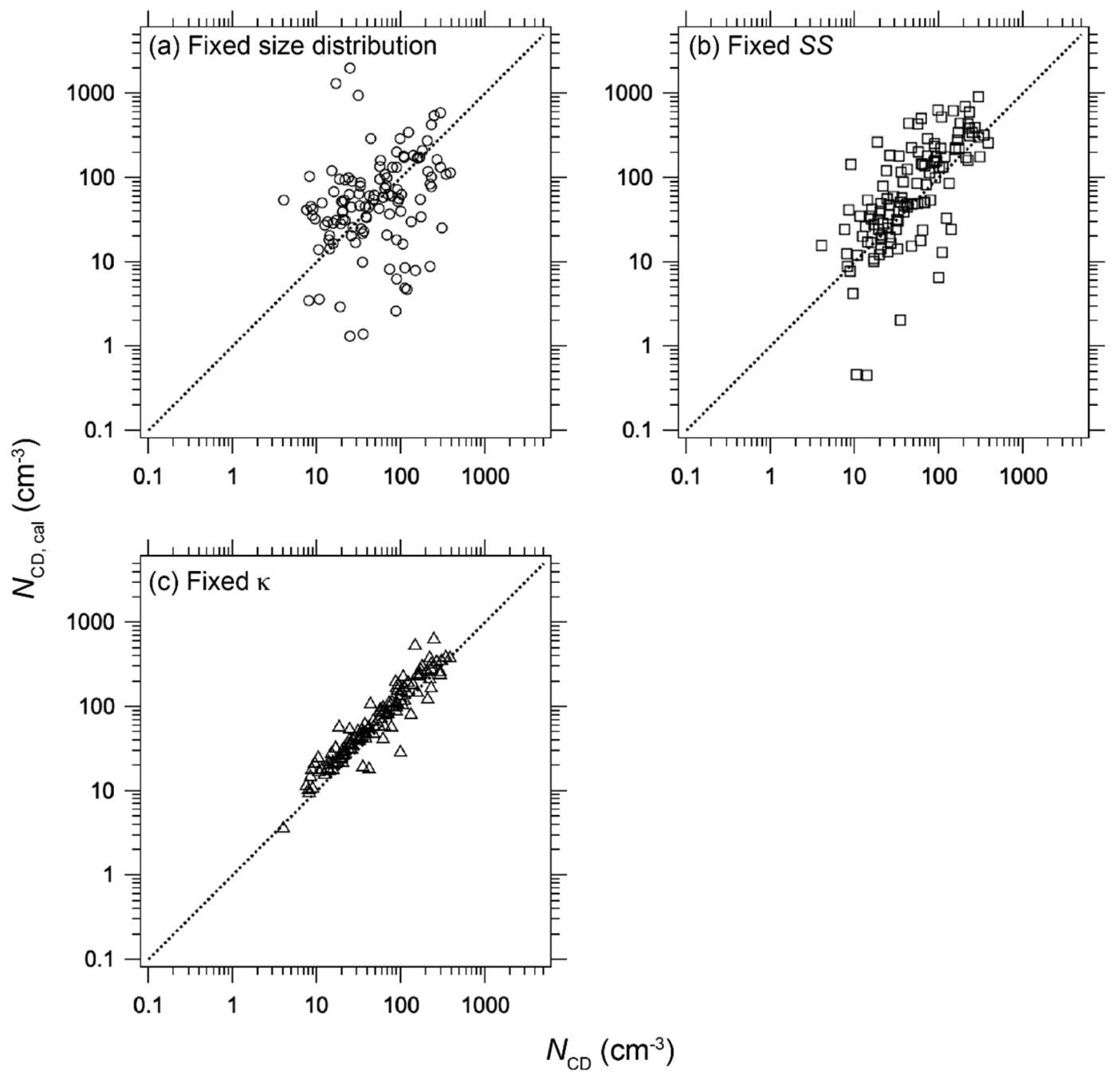

Figure 10. Calculated and measured $N_{\mathrm{CD}}$ during cloud-shrouded periods at the MFRS using the mean value of (a) the size distribution shape, (b) the water vapor supersaturation (SS) and (c) the hygroscopicity parameter $\kappa$.

\section{Concluding Remarks}

Atmospheric observations at a high mountain site located in the free troposphere, where the influence of long-range transport is significant, revealed clear differences in CCN and cloud droplet characteristics for different air mass origins. Both $\mathrm{CCN}$ and cloud droplet concentrations were significantly higher in continental air masses compared to those in air masses from the Pacific Ocean. The effective radius of the cloud droplets was also affected by the number concentration of cloud droplets, with smaller radii in the continental air masses. Based on the $\mathrm{CCN}$ characteristics and cloud droplet number concentration obtained by our observations, the water vapor supersaturation of the atmosphere was estimated to be equivalent to that estimated at other alpine sites. A calculation based on the Köhler theory to investigate the factors controlling the cloud droplet concentration showed that the most important factor is the aerosol particle size distribution, followed by the supersaturation and the chemical composition.

In evaluating the climatic impact of aerosol-cloud interactions, it is highly important to predict the cloud droplet number concentration which determines the optical properties of clouds. In this study, we clarified for the first time in East Asia that it is important to know the supersaturation degree of cloud rather than the chemical composition of aerosol particles for the prediction of cloud particle number concentration by the simultaneous observation of aerosol and cloud. This would be true in the case of well-mixed aerosols at locations remote from the sources like the free troposphere. Although it is difficult 
to directly measure the degree of cloud supersaturation, it will lead to a more precise prediction of cloud droplet number concentrations if the cloud supersaturations in various atmospheric environments are known by using the indirect method proposed in this study. For further understanding, it is also necessary to know factors controlling the degree of supersaturation simultaneously. Updraft velocity is an important factor, but is difficult to reproduce with a meteorological model in field observation of alpine sites where air stream is complicated. When conducting similar observations in mountain sites, it is necessary to acquire observation data of updraft velocity by installing multiple ultrasonic anemometers or releasing radiosondes from the foot of the mountain periodically.

Author Contributions: Methodology, A.W., Y.I. and K.M.; observation, A.W., R.K., Y.I. and K.M.; formal analysis, A.W., R.K. and Y.I.; investigation, A.W., R.K. and Y.I.; resources, K.M. and M.U.; writing-original draft preparation, A.W. and Y.I.; writing—review and editing, K.M. and M.U.; visualization, Y.I.; supervision, K.M.; project administration, K.M.; funding acquisition, K.M. All authors have read and agreed to the published version of the manuscript.

Funding: This work was supported by the Certified Nonprofit Organization (NPO) Mount Fuji Research Station. This work was performed during the period for which the Certified NPO Mount Fuji Research Station had received a part of the Mt. Fuji Weather Station from the Japan Meteorological Agency and managed it. This work was partly supported by JSPS KAKENHI Grant-in-Aid for Scientific Research (C) (Grant No. 25340017).

Institutional Review Board Statement: Not applicable.

Informed Consent Statement: Not applicable.

Data Availability Statement: Data concerning aerosol size distribution, CCN and cloud droplets are retrieved from https:/ / osf.io/68y2u/?view_only=03b0e1d2138c489c8fcbe36540e316d2. (Last accessed on 10 September 2021).

Acknowledgments: The authors gratefully acknowledge the NOAA Air Resources Laboratory (ARL) for the provision of the HYSPLIT transport and dispersion model and/or READY website (https: / / www.ready.noaa.gov; Last accessed on 12 August 2021) used in this publication. The authors thank Osamu Nagafuchi, Fukuoka Institute of Technology, for the providing the meteorological data. We appreciated critical review comments from two anonymous reviewers.

Conflicts of Interest: The authors declare no conflict of interest.

\section{References}

1. Köhler, H. The nucleus in and the growth of hygroscopic droplets. Trans. Faraday Soc. 1936, 32, 1152-1161. [CrossRef]

2. Dusek, U.; Frank, G.P.; Hildebrandt, L.; Curtius, J.; Schneider, J.; Walter, S.; Chand, D.; Drewnick, F.; Hings, S.; Jung, D.; et al. Size matters more than chemistry for cloud-nucleating ability of aerosol particles. Science 2006, 312, 1375-1378. [CrossRef]

3. Furutani, H.; Dall'osto, M.; Roberts, G.C.; Prather, K.A. Assessment of the relative importance of atmospheric aging on CCN activity derived from field observations. Atmos. Environ. 2008, 42, 3130-3142. [CrossRef]

4. Schmale, J.; Henning, S.; Decesari, S.; Henzing, B.; Keskinen, H.; Sellegri, K.; Ovadnevaite, J.; Pöhlker, M.L.; Brito, J.; Bougiatioti, A.; et al. Long-term cloud condensation nuclei number concentration, particle number size distribution and chemical composition measurements at regionally representative observatories. Atmos. Chem. Phys. 2018, 18, 2853-2881. [CrossRef]

5. Kim, C.K.; Yum, S.S. A numerical study of sea-fog formation over cold sea surface using a one-dimensional turbulence model coupled with the weather research and forecasting model. Bound.-Layer Meteorol. 2018, 143, 481-505. [CrossRef]

6. Stolaki, S.; Pytharoulis, I.; Karacostas, Y. A study of fog characteristics using a coupled WRF-COBEL model over Thessaloniki airport, Greece. Pure Appl. Geophys. 2012, 169, 961-981. [CrossRef]

7. Zhao, C.; Klein, S.A.; Xie, S.; Liu, X.; Boyle, J.S.; Zhang, Y. Aerosol first indirect effects on non-precipitating low-level liquid cloud properties as simulated by CAM5 at ARM sites. Geophys. Res. Lett. 2012, 39, L08806. [CrossRef]

8. Anttila, T.; Vaattovaara, P.; Komppula, M.; Hyvärinen, A.P.; Lihavainen, H.; Kerminen, V.M.; Laaksonen, A. Size-dependent activation of aerosols into cloud droplets at a subarctic background site during the second Pallas Cloud Experiment (2nd PaCE): Method development and data evaluation. Atmos. Chem. Phys. 2009, 9, 4841-4854. [CrossRef]

9. Asmi, E.; Freney, E.; Hervo, M.; Picard, D.; Rose, C.; Colomb, A.; Sellegri, K. Aerosol cloud activation in summer and winter at puy-de-Dôme high altitude site in France. Atmos. Chem. Phys. 2012, 12, 11589-11607. [CrossRef]

10. Ditas, F.; Shaw, R.A.; Siebert, H.; Simmel, M.; Wehner, B.; Wiedensohler, A. Aerosols-cloud microphysics-thermodynamicsturbulence: Evaluating supersaturation in a marine stratocumulus cloud. Atmos. Chem. Phys. 2012, 12, 2459-2468. [CrossRef] 
11. Hammer, E.; Bukowiecki, N.; Gysel, M.; Jurányi, Z.; Hoyle, C.R.; Vogt, R.; Baltensperger, U.; Weingartner, E. Investigation of the effective peak supersaturation for liquid-phase clouds at the high-alpine site Jungfraujoch, Switzerland (3580 $\mathrm{m}$ a.s.1.). Atmos. Chem. Phys. 2014, 14, 1123-1139. [CrossRef]

12. Moteki, N.; Mori, T.; Matsui, H.; Ohata, S. Observational constraint of in-cloud supersaturation for simulations of aerosol rainout in atmospheric models. npj Clim. Atmos. Sci. 2019, 2, 6. [CrossRef]

13. Adhikari, M.; Ishizaka, Y.; Minda, H.; Kazaoka, R.; Jensen, J.B.; Gras, J.L.; Nakajima, T. Vertical distribution of cloud condensation nuclei concentrations and their effect on microphysical properties of clouds over the sea near the southwest islands of Japan. J. Geophys. Res. 2005, 110, D10203. [CrossRef]

14. Hofmann, D.J.; Rosen, J.M.; Harder, J.W.; Hereford, J.V. Balloon-borne measurements of aerosol, condensation nuclei, and cloud particles in the stratosphere at McMurdo Station, Antarctica, during the spring of 1987. J. Geophys. Res. 1989, 94, 11253-11269. [CrossRef]

15. Henning, S.; Weingartner, E.; Schmidt, S.; Wendisch, M.; Gäggeler, H.W.; Baltensperger, U. Size-dependent aerosol activation at the high-alpine site Jungfraujoch (3580 m asl). Tellus B 2002, 54, 82-95. [CrossRef]

16. Jurányi, Z.; Gysel, M.; Weingartner, E.; Bukowiecki, N.; Kammermann, L.; Baltensperger, U. A 17 month climatology of the cloud condensation nuclei number concentration at the high alpine site Jungfraujoch. J. Geophys. Res. 2011, 116, D10204. [CrossRef]

17. Kammermann, L.; Gysel, M.; Weingartner, E.; Baltensperger, U. 13-month climatology of the aerosol hygroscopicity at the free tropospheric site Jungfraujoch (3580 m a.s.l.). Atmos. Chem. Phys. 2010, 10, 10717-10732. [CrossRef]

18. Motos, G.; Schmale, J.; Corbin, J.C.; Modini, R.L.; Karlen, N.; Bertò, M.; Baltensperger, U.; Gysel-Beer, M. Cloud droplet activation properties and scavenged fraction of black carbon in liquid-phase clouds at the high-alpine research station Jungfraujoch (3580 m a.s.1.). Atmos. Chem. Phys. 2019, 19, 3833-3855. [CrossRef]

19. Henning, S.; Dieckmann, K.; Ignatius, K.; Schäfer, M.; Zedler, P.; Harris, E.; Sinha, B.; Van Pinxteren, D.; Mertes, S.; Birmili, W.; et al. Influence of cloud processing on CCN activation behaviour in the Thuringian Forest, Germany during HCCT-2010. Atmos. Chem. Phys. 2014, 14, 7859-7868. [CrossRef]

20. Friedman, B.; Zelenyuk, A.; Beranek, J.; Kulkarni, G.; Pekour, M.; Gannet Hallar, A.; McCubbin, I.B.; Thornton, J.A.; Cziczo, D.J. Aerosol measurements at a high-elevation site: Composition, size, and cloud condensation nuclei activity. Atmos. Chem. Phys. 2013, 11839-11851. [CrossRef]

21. Hsiao, T.C.; Ye, W.C.; Wang, S.H.; Tsay, S.C.; Chen, W.N.; Lin, N.H.; Lee, C.T.; Hung, H.M.; Chuang, M.T.; Chantara, S. Investigation of the CCN activity, BC and UVBC mass concentrations of biomass burning aerosols during the 2013 BASELInE campaign. Aerosol Air Qual. Res. 2016, 16, 2742-2756. [CrossRef]

22. Kato, S.; Shiobara, Y.; Uchiyama, K.; Miura, K.; Okochi, H.; Kobayashi, H.; Hatakeyama, S. Atmospheric $\mathrm{CO}_{3} \mathrm{O}_{3}$, and $\mathrm{SO}_{2}$ measurements at the summit of Mt. Fuji during the summer of 2013. Aerosol Air Qual. Res. 2016, 16, 2368-2377. [CrossRef]

23. Nomura, S.; Mukai, H.; Terao, Y.; Machida, T.; Nojiri, Y. Six years of atmospheric $\mathrm{CO}_{2}$ observations at Mt. Fuji recorded with a battery-powered measurement system. Atmos. Meas. Tech. 2017, 10, 667-680. [CrossRef]

24. Roberts, G.C.; Nenes, A. A Continuous-Flow Streamwise Thermal-Gradient CCN Chamber for Atmospheric Measurements. Aerosol Sci. Tech. 2005, 39, 206-221. [CrossRef]

25. Brechtel, F.J.; Kreidenweis, S.M. Predicting Particle Critical Supersaturation from Hygroscopic Growth Measurements in the Humidified TDMA. Part II: Laboratory and Ambient Studies. J. Atmos. Sci. 2000, 57, 1872-1887. [CrossRef]

26. Muraki, H. Fuji Sancho no Kaze no Kansoku. Kishou Kenkyu Note 1974, 118, 65-74. (In Japanese)

27. Petters, M.D.; Kreidenweis, S.M. A single parameter representation of hygroscopic growth and cloud condensation nucleus activity. Atmos. Chem. Phys. 2007, 7, 1961-1971. [CrossRef]

28. Rose, D.; Gunthe, S.S.; Mikhailov, E.; Frank, G.P.; Dusek, U.; Andreas, M.O.; Pöschl, U. Calibration and measurement uncertainties of a continuous-flow cloud condensation nuclei counter (DMT-CCNC): CCN activation of ammonium sulfate and sodium chloride aerosol particles in theory and experiment. Atmos. Chem. Phys. 2008, 8, 1153-1179. [CrossRef]

29. Seinfeld, J.H.; Pandis, S.N. Cloud Physics. In Atmospheric Chemistry and Physics: From Air Pollution to Climate Change, 2nd ed.; John Wiley \& Sons, Inc.: Hoboken, NJ, USA, 2006; pp. 761-827.

30. Rolph, G.; Stein, A.; Stunder, B. Real-time environmental applications and display sYstem: READY. Environ. Model. Softw. 2017, 95, 210-228. [CrossRef]

31. Stein, A.F.; Draxler, R.R.; Rolph, G.D.; Stunder, B.J.; Cohen, M.D.; Ngan, F. NOAA's HYSPLIT atmospheric transport and dispersion modeling system. Bull. Am. Meteorol. Soc. 2015, 96, 2059-2077. [CrossRef]

32. Hasegawa, T.; Miura, K.; Iinuma, K.; Kobayashi, H. Measurement of Cloud Condensation Nuclei at the summit of Mt. Fuji. Earozoru Kenkyu 2012, 27, 189-196. (In Japanese with English abstract)

33. Zhou, S.; Collier, S.; Jaffe, D.A.; Zhang, Q. Free tropospheric aerosols at the Mt. Bachelor Observatory: More oxidized and higher sulfate content compared to boundary layer aerosols. Atmos. Chem. Phys. 2019, 19, 1571-1585. [CrossRef]

34. Suzuki, I.; Hayashi, K.; Igarashi, Y.; Takahashi, H.; Sawa, Y.; Ogura, N.; Akagi, T.; Dokiya, Y. Seasonal variation of water-soluble ion species in the atmospheric aerosols at the summit of Mt. Fuji. Atmos. Environ. 2008, 42, 8027-8035. [CrossRef]

35. Jimenez, J.L.; Canagaratna, M.R.; Donahue, N.M.; Prevot, A.S.; Zhang, Q.; Kroll, J.H.; DeCarlo, P.F.; Allan, J.D.; Coe, H.; Ng, N.L.; et al. Evolution of organic aerosols in the atmosphere. Science 2009, 326, 1525-1529. [CrossRef]

36. Kaneyasu, N.; Igarashi, Y. Light absorption characteristics of atmospheric aerosols observed at the summit of Mt. Fuji in early summer. Earozoru Kenkyu 2007, 22, 318-321. (In Japanese with English abstract) 
37. Gunthe, S.S.; King, S.M.; Rose, D.; Chen, Q.; Roldin, P.; Farmer, D.K.; Jimenez, J.L.; Artaxo, P.; Andreae, M.O.; Martin, S.T.; et al. Cloud condensation nuclei in pristine tropical rainforest air of Amazonia: Size-resolved measurements and modeling of atmospheric aerosol composition and CCN activity. Atmos. Chem. Phys. 2009, 9, 7551-7575. [CrossRef]

38. Iwamoto, Y.; Kinouchi, K.; Watanabe, K.; Yamazaki, N.; Matsuki, A. Simultaneous measurement of CCN activity and chemical composition of fine-mode aerosols at Noto peninsula, Japan, in autumn 2012. Aerosol Air Qual. Res. 2016, 16, 2107-2118. [CrossRef]

39. Rose, D.; Nowak, A.; Achtert, P.; Wiedensohler, A.; Hu, M.; Shao, M.; Zhang, Y.; Andreae, M.O.; Pöschl, U. Cloud condensation nuclei in polluted air and biomass burning smoke near the mega-city Guangzhou, China-Part 1: Size-resolved measurements and implications for the modeling of aerosol particle hygroscopicity and CCN activity. Atmos. Chem. Phys. 2010, 10, 3365-3383. [CrossRef]

40. Tunved, P.; Ström, J.; Hansson, H.C. An investigation of processes controlling the evolution of the boundary layer aerosol size distribution properties at the Swedish background station Aspvreten. Atmos. Chem. Phys. 2004, 4, 2581-2592. [CrossRef]

41. Khvorostyanov, V.I.; Curry, J.A. Clouds and Their Properties. In Thermodynamics, Kinetics, and Microphysics of Clouds; Cambridge University Press: New York, NY, USA, 2014; pp. 9-44.

42. Bennartz, R.; Rausch, J. Global and regional estimates of warm cloud droplet number concentration based on 13 years of AQUA-MODIS observations. Atmos. Chem. Phys. 2017, 17, 9815-9836. [CrossRef]

43. Twomey, S. The nuclei of natural cloud formation part II: The supersaturation in natural clouds and the variation of cloud droplet concentration. Geofis. Pura Appl. 1959, 43, 243-249. [CrossRef] 